\title{
Predicting Strategy and Listening Comprehension
}

\author{
Yongmei Jiang \\ Foreign Language School \\ Qingdao University of Science and Technology \\ Qingdao 266061, Shandong, China \\ E-mail: yongmeijiang716@126.com
}

\begin{abstract}
The author found certain potential obstacles that students encounter in their listening class, which she believes should be removed by a good class teaching method. However, traditional listening class fails. She goes on to explore integrating strategies into listening class, among the many strategies she choose the prediction strategy and describes it in three stages: Pre-listening, while-listening, and post-listening. Then a real model of applying prediction in listening class is given, whose effects are tested and proved efficient.
\end{abstract}

Keywords: Prediction, Strategy, Listening, Obstacles, Model

\section{Introduction}

As one of the fundamental language skills, listening is a medium through which listeners gain a large portion of their information. Especially in this age of mass communication, it is of vital importance that our students are taught to listen effectively and critically. Foreign language teachers increasingly agree on the need to teach listening comprehension as a separate skill. For language learners, listening is the skill that makes the heaviest processing demands, because learners must store information in short-term memory at the same time as they are working to understand the information. Thus, despite the recognition of the critical role it plays in communication, listening remains one of the least understood processes in language learning (Morley, 1991). In China, many students learning English are frustrated by listening and frantic for ways to improve their listening comprehension, but with little success.

\section{Integrating strategies into listening comprehension}

\subsection{Potential obstacles for students in listening comprehension}

In every two years I make investigations among the newcomers of my classes about their English study. Through these investigations, I've found out certain potential obstacles or difficulties that students encounter in their listening class.

- They found it difficult to keep up with the speakers in the tape recording, when they are busy working out the meaning of one part of what they hear, they miss what comes next.

- They are not familiar with the pronunciation of certain words or the accent of the speaker. They sometimes are unable to recognize words that they know in writing or words that even sound familiar to them.

Their vocabulary is limited. Just as Underwood $(1989,17)$ said, "for people listening to a foreign language, an unknown word can be like a suddenly dropped barrier causing them to stop and think about the meaning of the word and thus making them miss the next part of the speech."

Accordingly the effective listening class should at least able to remove the obstacles for the students. Let's check if our traditional listening class is capable of this.

\subsection{Traditional listening class and its shortcomings}

Traditionally, listening comprehension has often been regarded as a passive language skill and so, in classrooms, listening comprehension classes follow a relatively consistent format:

- $\quad$ Teaching of new vocabulary;

- $\quad$ Extensive listening (for general understanding of the context);

- $\quad$ Intensive listening (for some details); 
- $\quad$ Doing the comprehension exercises;

- $\quad$ Checking answers;

- $\quad$ Explaining some difficult language points.

In classes such as this, listening is not taught but tested. Teachers focus on the outcome of listening, rather than on listening itself, upon product rather than process (Field, 1998). They do little or nothing to get rid of the obstacles students frequently encounter.

\subsection{The necessity to integrating strategies listening comprehension}

From the above format we can see that traditional teaching of listening comprehension fails to understand the mental processes that the EFL learners use in listening comprehension and it also fails to understand the deliberate strategies for comprehending language texts, for processing new information, and for learning and retaining concepts related to academic language and content (O’ Malley, 1985).

To overcome the shortcomings of traditional listening class, Rubin (1994:199) suggests that it is the teacher's responsibility to teach students how to listen and that the strategy-based approach is the one that will bring the biggest improvements in comprehension. Teachers need help their students by making them aware of the strategies they use in their native language and introduce them to some new strategies in listening to a foreign language. In addition, language teachers now should consider the learners' strategies as integral elements in the design and implementation of effective language teaching.

\section{The prediction strategy}

Underwood (1989:30) said, "it is unfair to plunge students into the listening text, even when testing rather than teaching listening comprehension, as this makes it extremely difficult for them to use the natural listening skills (which we all use in our native language) of matching what they hear with what they expect to hear and using their previous knowledge to make sense of it."

Although there are many types of listening strategies (predicting, summarizing, distinguishing fact from opinion, interpreting tone, drawing inferences, etc.), this essay is going to dwell on prediction because it comes first and accounts for a comparatively larger importance.

\subsection{What is prediction strategy}

Prediction, or looking ahead, is a basic strategy for using prior knowledge to understand a text. The learner generates a hypothesis about the type, purpose, or scope of a text to provide a framework for transacting with the text to confirm comprehension.

Our interpretation of what we hear depends to a large extent on what we expect to hear. If what we hear does not meet our expectations, it may sometimes lead to misinterpretation. On the other hand, if we can predict accurately what we shall hear next, our listening will be much more efficient. There are very few occasions when people listen without having some idea of what they expect to hear.

The skill of prediction depends largely on one's prior knowledge of the world and of the language, how much one knows about the speaker, and how much one knows about the speaker's intent. Thus the initial stage of the training program for developing the predictive skill should concentrate on getting the students to become aware of their own prior knowledge and to use this prior knowledge as their basis for prediction and comprehension.

\subsection{The application of prediction strategy}

\subsubsection{Pre-listening}

This is a very important stage for listening class. The teacher could get the students ready to listen by doing the following instructions in three steps:

Step one: Help them by doing the following:

- Inform them the background information

- Teach new vocabulary and grammar forms relevant to the material.

- Translate some words they might not be familiar with or some sentences difficult to understand.

Step two: Conduct group discussions for the students to remind each other:

- The speaker and the speaker's possible purpose.

- $\quad$ Students' purpose for listening: to learn specific information; to understand most or all of the message.

- Students' knowledge/experience with the subject: think about what they already know about the subject.

Step three: Predict what they will be hearing: 
- $\quad$ The format (how the message is organized and in what sequence)

- $\quad$ Key words, phrases or sentences they might expect to hear.

- The information or opinions

3.2.2 While-listening

While the students are listening they need to monitor their comprehension by:

- $\quad$ Check the accuracy of their predictions.

- Deny some predictions and form new ones which may soon be denied again.

- Decide what is and is not important to understand.

3.2.3 Post-listening

These strategies might help the students to synthesize, interpret and evaluate what they've heard:

- $\quad$ Check what predictions are correct/incorrect and helpful/useless, why.

- $\quad$ Consider what they heard and how it fits with what they know.

- Discuss the prediction strategy they used to listen - how much did they benefit from it?

- $\quad$ Conclude how to make a better prediction next time.

\subsection{A model of applying prediction in listening class}

The material used is a text titled Being a Police Officer Is a Stressful Job from Unit 4 in College English Listening and Speaking Course 3 by Shanghai Foreign Language Education Press. The procedure is as follows:

Pre-listening: Step one:

- Inform the students some background information: what does stressful mean? What causes stress to people? What do police officers usually do on job? A story from the newspaper: A patrolling police officer stopped a driver for drunk drive but was suddenly stabbed by the driver and he was seriously wounded.

- $\quad$ Teach the new vocabulary from the text: explain the usage and teach how to read correctly.

- Translate some phrases from the text they might not be familiar with, eg. different types of assignments, supervising investigation, the fear factor, during a routine stop.

Step two: based on the title and the following choices:

(1) a. Friends.

b. A police officer and an investigator.

c. Two police officers.

d. A police officer and a program hostess.

(2) a. His job as a police officer.

b. His personal life.

c. How stressful patrol work is.

d. How police officers are taught to deal with stress.

(3) a. He is an experienced police officer.

b. He will quit his present job sooner or later.

c. He is a good supervisor.

d. He enjoys being a police officer.

Ask the students to have group discussions of some questions:

- What is your knowledge/experience about the police officers' job?

- What might be the speakers' topic and purpose?

- What do you think the tree questions might be?

After the discussion, the teacher can check their answers. They must have got some new information from their partners or have come up with some new ideas. Piercing all the fragments of information together, the whole class will have a general picture of the police officers' job.

By analyzing the choices we can predict that the three questions might be: 
(1) What's the relationship between the two speakers?

(2) What does the man mean or talk about?

(3) What is the man like or what do we know about him from the conversation?

Step three: predict what they will be hearing:

- the format: the text will be a conversation.

- the language and information they might expect to hear, including specific words and phrases: (this is open)

- What do you want to find out in the text: some stories or examples about the police officers' job showing that it is stressful.

While-listening : This stage should be done by the students. The teacher could only remind them to do this at the end of the pre-listening stage of what has suggested in 3.2.2 and then instruct them after all the exercises have been finished in the post-listening stage as in 3.2.3.

Post-listening: After they have finished listening to the text, the teacher should remind the students to check their predictions as suggested in 3.2.3. Take the following part from the dialogue for example:

Interviewer: Sam, I think most people would say that being a police officer is a very stressful job. Would you agree? (s1)

Sam: Yes, it's definitely a stressful job. But it depends on your assignment. (s2)

Interviewer: So, what's probably the most stressful assignment you can have? (s3)

Sam: I'd say patrol is the most stressful assignment. (s4)

Interviewer: That's interesting! In what way? (s5)

When the listeners hear $s 1$, since they have predicted according to the title that police officers' job is stressful, they should predict that the answer should agrees to this question. So, when they hear the second part of $s 2$, they should only allow themselves to be a little doubtful about their prediction. When they get $s 3$, they can be assured and feel relaxed. When the listeners get $s 5$, they should predict that what will come next is to explain why the patrol work is stressful.

\subsection{The effects of applying prediction into listening class}

To examine the effects of the prediction strategy, the author did a quiz with the material mentioned at the beginning of 3.3 which comprises of two exercises (Exercise one comprises of three multiple choices as listed in 3.3 with a full mark of 6 points and exercise two of ten blanks to be filled with the missing information with a full mark of 20 points).

Both the two classes I am currently teaching are grade two students majoring in Information and of the same English level.

I instructed Class One (55 students) how to use prediction strategy in listening class for two times, and at the second time we had a quiz.

To make a comparison, I didn't instruct Class Two (58 students) this strategy and only use the traditional method as mentioned in 2.2 .

The answer sheet was collected in each class soon after they finished. All the sheets were valid. I graded all the sheets $(55+58)$, and computed the average points of each class for each exercise, as is shown in the following table clearly.

\begin{tabular}{|l|l|l|}
\hline & Class One (55) & Class Two (58) \\
\hline Exercise one (6) & 5.56 & 4.43 \\
\hline Exercise two (20) & 15.25 & 11.86 \\
\hline
\end{tabular}

From this simple table above, we can clearly see that the prediction strategy really helps the experimental group to get high marks and especially so in exercise two.

After class, the author interviewed six students of different English levels from Class One and concluded the effects of prediction strategy as follows:

(1) It rouses their original knowledge on the topic and makes it familiar.

(2)The informing of new words and phrases from the text gets them well prepared and therefore the text sounds easier.

(3) It makes the questions much easier because they could listen very effectively, and actually they have already known what they are going to hear. 
(4) It makes their mind busy and active, which greatly reduced the tendency to be sleepy on listening class.

(5) It really relaxes their nerves, so listening becomes efficient.

We can see that by prediction, the students will find listening class isn't very boring. On the contrary, by making and checking predictions, they will have some small victories and can smile with that. The most important thing is that listening becomes easier, and the following exercises become easier naturally. The great differences shown in the above table and the attractive effects may be very persuasive for other teachers also try and test.

\section{Conclusion}

Although the positive effect of employing the prediction strategy is obvious, it is not enough to use just one strategy to make listening class effective to its utmost. Actually we need make good use of all the strategies possible and necessary to achieve this goal because it is generally acknowledged that there are no good or bad strategies, but there is indeed good or bad use of strategies. "With some exceptions, strategies themselves are not inherently good or bad, but have the potential to be used effectively." (Cohen, 1998:8). Therefore, the author strongly advocates that teachers be given valuable guidance and training in instructing strategies by the experts and the research institutions concerned.

\section{References}

Cohen, A. (1998). Strategies in Learning and Using a Second Language. London: Longman.

Field, J. (1998). Skills and Strategies: towards a new methodology for listening. ELT Journal, 52, 110-118.

Morley, J. M. (1991). Listening Comprehension in Second/Foreign Language Instruction. In M. Celce-Murcia (ed.) Teaching English as a Second Language or Foreign Language. Massachusetts: Heinle and Heinle Publishers.

O’Malley, J. M. (1985). Learning strategies used by beginning and intermediate ELS students. Language Learning, 35, 21-46.

Rubin, J. (1994). A review of second language listening comprehension research. Modern Language Journal, 78(2), 199-221.

Underwood, M. (1989). Teaching Listening. New York: Longman Inc. 